Elsevier Editorial System(tm) for Sensors \& Actuators: B. Chemical Manuscript Draft

Manuscript Number: SNB-D-11-01569R1

Title: A Micro Heater Platform with Fluid Channels for testing Micro-Solid Oxide Fuel Cell components

Article Type: Eurosensors 2011

Keywords: micro-scale solid oxide fuel cell; gas processing unit; hydrocarbon reforming

Corresponding Author: Mr Bo Jiang,

Corresponding Author's Institution: EPFL

First Author: Bo Jiang

Order of Authors: Bo Jiang; Paul Muralt, Ph.D.; Peter Heeb; Alejandro J. Santis-Alvarez; Majid Nabavi, Ph.D.; Dimos Poulikakos, Ph.D.; Philippe Niedermann, Ph.D.; Thomas Maeder, Ph.D.

Abstract: Micro-scale solid oxide fuel cells ( $\mu$-SOFCs) constitute a promising power generation technology for portable devices such as aerospace exploration, medical devices and consumer electronics. Fuel cell systems include several functional units providing gas reforming, electrochemical power generation, and post-combustion of unused fuel. All such units require operation at controlled temperature with appropriate gases. Although various $\mu$-SOFC components have been demonstrated, the evaluation of the thermal balance is cumbersome, as there is no micro platform providing thermal insulation, controlled heating, temperature control, and gas exchange. Our testing platform is designed for this purpose. It consists of two sealed glass substrates with integrated platinum thermistors for heating and temperature control, and channels to supply and evacuate gases. Its fabrication is compatible with silicon chip bonding. The heating elements are thick-film platinum thermistors allowing to heat up to $700^{\circ} \mathrm{C}$. Efficient thermal decoupling along the carrier allows convenient lowtemperature electrical and fluidic connections. A fluidic MEMS module - a prototype gas reformer - was bonded onto the carrier to demonstrate tight gas connections at elevated temperature. 


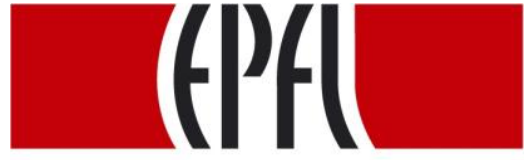

ÉCOLE POLYTECHNIQUE FÉDÉRALE DE LAUSANNE
Laboratoire de Production Microtechnique (LPM)

Bo Jiang

BM 1.136, EPFL, Station 17, CH-1015, Lausanne, Switzerland

Tel: ++41 (21) 6937781

Fax: ++41 (21) 6933891

E-mail: bo.jiang@epfl.ch

Dear Reviewers,

Thank you very much for your efforts on reviewing my paper (SNB-D-11-01569). However, due to the new agreement with my paper's collaborators, some of the figures and contents in the original paper need to be modified and improved. The title of my paper changes to "A Micro Heater Platform with Fluid Channels for testing Micro-Solid Oxide Fuel Cell components". The content of the updated version, as you may read from the abstract, put more emphasis on discussion of fabrication and testing of the micro heater platform for testing micro-solid oxide fuel cell components, which is an essential step for the testing of the Micro-Solid Oxide Fuel Cell system in near future.

I would appreciate your time and efforts deeply on reviewing my updated version.

Best regards,

Bo Jiang 


\title{
A Micro Heater Platform with Fluid Channels for testing Micro- Solid Oxide Fuel Cell components
}

\author{
Bo Jiang ${ }^{\mathrm{a}, \mathrm{e}}$, Paul Muralt ${ }^{\mathrm{a}}$, Peter Heeb ${ }^{\mathrm{b}}$, Alejandro J. Santis-Alvarez ${ }^{\mathrm{c}}$, Majid Nabavi ${ }^{\mathrm{c}}$, Dimos \\ Poulikakos ${ }^{c}$,Philippe Niedermann ${ }^{d}$, Thomas Maeder ${ }^{\mathrm{e}}$ \\ ${ }^{a}$ Ceramic Laboratory, EPFL, Lausanne, Switzerland \\ ${ }^{b}$ Institute for Micro- and Nanotechnology, NTB, Buchs, Switzerland \\ 'Laboratory of Thermodynamics in Emerging Technology, ETHZ, Zürich, Switzerland \\ ${ }^{d}$ Centre Suisse d'Electronique et de Microtechnique (CSEM), Neuchâtel, Switzerland \\ ${ }^{e}$ Laboratory of Microengineering for Manufacturing, EPFL, Lausanne, Switzerland
}

\begin{abstract}
Micro-scale solid oxide fuel cells ( $\mu$-SOFCs) constitute a promising power generation technology for portable devices such as aerospace exploration, medical devices and consumer electronics. Fuel cell systems include several functional units providing gas reforming, electrochemical power generation, and post-combustion of unused fuel. All such units require operation at controlled temperature with appropriate gases. Although various $\mu$-SOFC components have been demonstrated, the evaluation of the thermal balance is cumbersome, as there is no micro platform providing thermal insulation, controlled heating, temperature control, and gas exchange. Our testing platform is designed for this purpose. It consists of two sealed glass substrates with integrated platinum thermistors for heating and temperature control, and channels to supply and evacuate gases. Its fabrication is compatible with silicon chip bonding. The heating elements are thick-film platinum thermistors allowing to heat up to $700^{\circ} \mathrm{C}$. Efficient thermal decoupling along the carrier allows convenient low-temperature electrical and fluidic connections. A fluidic MEMS module - a prototype gas reformer - was bonded onto the carrier to demonstrate tight gas connections at elevated temperature.
\end{abstract}

Keywords: micro-scale solid oxide fuel cell; gas processing unit; hydrocarbon reforming

\section{Introduction}

The demand for portable power storage and delivery systems has greatly increased in the past decades with the development of portable electronics such as portable computing devices, medical devices and personal electronic devices. To meet such needs, micro-scale solid oxide fuel cell systems ( $\mu$-SOFCs) are studied as an alternative, promising power generation technology [1]. As a solid-state device, the $\mu$-SOFC electrochemically converts chemical energy into electrical energy, offering high energy density and fuel flexibility [2], which can employ common hydrocarbon fuel such as butane or propane with using an additional gas processing approach. This additional step in the $\mu$-SOFCs aims to reform fuels to syngas $\left(\mathrm{H}_{2}\right.$ and $\left.\mathrm{CO}\right)$, avoiding coking at the $\mu$-SOFC membrane and enhancing the working efficiency [3]. Moreover, it is reported recently that a high yield of syngas can be achieved through a catalytic partial oxidation (POX) of $n$-butane in a micro-reactor [4-6]. The POX is an exothermic reaction that can be used as start-up energy for the $\mu$-SOFC [7]. However, no integrated micro-scale platform for testing the $\mu$-SOFC and its gas processing is available so far, which prompted us to develop such a device in this work. The design and fabrication of the testing platform with integration of 
fluidic connection, mechanical support and temperature regulation are presented, and its heating performance is examined using an in-house voltage regulation module. Finally, the performance of the gas connection is demonstrated by attaching a prototype gas forming MEMS unit.

\section{Design of a $\mu$-SOFC testing system}

In order to test the $\mu$-SOFC components reliably and accurately, the testing platform has to meet requirements including thermal regulation with an adequate power supply that can heat them up to the desired temperature. Additionally, the platform is supposed to provide a large degree of thermal decoupling between the high-temperature zone (hot end) hosting the component and the low-temperature zone (cold end) that allows the use conventional fluidic and electrical connections, rendering the testing easy and efficient. Therefore, we proposed a simple concept of sealing the part on a thermally matched and temperature-regulated glass carrier (Fig. 1). The carrier itself was soldered onto a thick-film ceramic base that allowed a reliable and welldefined electrical and thermal interface to the testing jig (Fig. 2). The carrier was designed as a beam of dimensions $75 \times 12 \times 1.7 \mathrm{~mm}^{3}$, consisting of two pieces of aluminosilicate glass substrates (Schott AF32, Schott AG), one is in thickness of $0.5 \mathrm{~mm}$ thick and another one is 0.7 $\mathrm{mm}$ thick, bonded by an additional sealing glass layer. The layout of the sealing glass layer consists of two rectangular shaped rings individually placed at the edge and inside the carrier, which defines two parallel inlet channels at the sides of the carrier and one outlet channel at the center, between both glass plates. This rather simple design was chosen over more advanced approaches such as three dimensional patterning of low-temperature co-fired ceramic (LTCC) [8-11], as it allows a wider selection of substrate materials in order to achieve close thermal expansion match with a wide range of parts, ranging from micromachined silicon to stabilized zirconia. The cross-section area of the inlet fluidic channel was proposed to be $2 \times 0.2$ $\mathrm{mm}^{2}$ in order to minimize pressure drop of the inlet $\mathrm{n}$-butane gas. Two holes with a diameter of $2 \mathrm{~mm}$ were drilled at the hot end of the lid for connecting the $\mu$-SOFC part, and another two holes with same diameter at the cold end were used for external gas connections (Figures 1). The part to be tested was glass-sealed onto the carrier, although other methods may be envisioned (metal-glass composite, nano-silver sintering, etc.). The temperature regulation was integrated onto the carrier by using a thick-film self-heating thermistor concept [12]. Here, two thick-film platinum heaters were deposited at the back side of the bottom glass substrate underneath the $\mu$-SOFC part. These heaters also act as self-heating thermistors due to the positive temperature dependence of their resistance [13]. They were extended to the cold end by thick-film silver conductors, which also defined the solder pads allowing attachment and electrical interconnection to the ceramic base (Fig. 2). The use of silver conductors can reduce the overall resistance of the heating elements and optimizes the production cost. 
Figure 1

\section{Experimental}

Fabrication of the carrier

In order to print sealing glass onto the designed carrier plates, a glass frit powder (Ferro IP760c, $35 \%$ by weight) was made into a printable paste by mixing with organic vehicle ( $65 \%$ by weight) using a three-roll mill. The organic vehicle was made (by weight) of 57.1\% terpineol (Fluka), $23.8 \%$ bis (2-butoxyethyl)ether (Sigma-Aldrich), 14.3\% triethylene glycol bis(2-ethylhexanoate) (Sigma-Aldrich) and 4.8\% ethylcellulose (Sigma-Aldrich, "300 cps" grade, 48\% ethoxy substitution of $\mathrm{OH}$ groups), which were mixed using a hotplate stirrer (Fisher Scientific, USA) at ca. $80^{\circ} \mathrm{C}$ and $300 \mathrm{rpm}$ for 2 hours (Table 1). The figure 3 shows the process flow of assembling the carrier. The thick-film Pt thermistors (Heraeus CL11-6109) were first screen-printed (Aurel C900, Italy) onto the back side of the bottom carrier plate and fired in a belt furnace (Sierratherm, USA) at $850^{\circ} \mathrm{C}$ for 10 minutes with a ramp rate of $20 \mathrm{~K} / \mathrm{min}$ (Fig.3-2). Secondly, asprepared sealing glass paste was printed onto both top and bottom glass substrates and dried at $150^{\circ} \mathrm{C}$ for 10 minutes. Such a printing-drying cycle repeated 5 times. Then the glass substrates with the sealing glass were assembled together and sealed at $725^{\circ} \mathrm{C}$ for 20 minutes with a ramp rate of $20 \mathrm{~K} / \mathrm{min}$ (Figure 3-3). A weight of 80 grams was placed onto the carrier with a contact area of $0.9 \mathrm{~cm}^{2}$ during the firing. A micro-fabricated fluidic MEMS device, consisting of a micromachined silicon part that is anodically bonded by a piece of Pyrex, was used to demonstrate the gas connections (Figure 3-1). After fabrication of the carrier and the MEMS device, a layer of sealing glass was printed onto the Pyrex side of the device, which was then placed and sealed onto the hot end of the carrier at $675^{\circ} \mathrm{C}$ for $20 \mathrm{~min}$ with ramp rate of $19 \mathrm{~K} / \mathrm{min}$ (Fig.3-4). Afterwards, thick-film Ag conductors and solder pads were printed the back side of the carrier using two types of Ag conductors (ESL 590-G and DuPont 6145), connecting the thick-film Pt thermistors and having solder terminals at the "cold" end (Fig.3-5). The conductors were then fired at $500^{\circ} \mathrm{C}$ for 20 minutes with ramp rate of $14 \mathrm{~K} / \mathrm{min}$. Finally, the resulting sample was attached onto a ceramic base (Fig. 3-6) via soldering (62\% $\mathrm{Sn}+36 \% \mathrm{~Pb}+2 \% \mathrm{Ag}$ by weight, Nordson EFD). Two fluidic connectors (Fig. 3-7) were glued onto the cold end using epoxy (STYCAST 2741 W1 - Catalyst 15, Emerson \& Cuming).

Table 1

Figure 2

Testing platform 
The ceramic base with soldered carrier was installed onto an aluminum mechanical base (Figure 2f). The printed circuit board for measuring the temperature of thick-film Pt thermistor was connected to the ceramic base through spring contacts, providing the electrical connection from an in-house made voltage regulate module (Figure 2e). Two pieces of thermal blocks (WDS@ Ultra, thermal conductivity at $500^{\circ} \mathrm{C}: 0.027 \mathrm{~W} / \mathrm{m} / \mathrm{K}$, Figure $2 \mathrm{~g}$ ) covered the carrier and the attached fluidic MEMS module.

Figure 3

\section{Characterization}

The thickness of fired thick-film Pt thermistors and thick-film Ag conductors were characterized by a non-contact profilometer (BMT, Germany). The dimension of the sealing glass in the carrier and the fluidic channels in the carrier were analyzed by observing the carrier at its cross-section under a microscope (Leica M165C, Germany).

The hermeticity of the glass sealing in the carrier was examined using the dye penetrating testing method. After the carrier was sealed, the dye (Allura Red AC, Sigma-Aldrich) was injected into the fluidic channels in the carrier and the sample was observed under the microscope. If there were cracks in the sealing glass, the dye would flow through the cracks which can be identified by the red color of the dye.

The heating capability and thermal power of the system were characterized by the voltage regulation module. The temperature at the hot end of the carrier by heating the thick-film Pt thermistors is accurately calibrated by using a Pt1000 temperature sensor (Heraeus). Applying a $22 \mathrm{~V}$ of constant voltage to the carrier, the temperature at the hot end is indicated by the thickfilm Pt thermistors, and that at the cold end is measured by a Pt1000 temperature sensor. The time and the electrical power consumed at the carrier to reach $600^{\circ} \mathrm{C}$ in steady-state were measured to analyze the heating rate and thermal power of the system.

The assembled test module was connected to the gas supply and heated up from $500^{\circ} \mathrm{C}$ to $550^{\circ} \mathrm{C}$. The mixture of butane and air gas was used as the carried gas for testing the pressure drop. The volumetric flow rate of the carried gas at inlet and outlet was measured and calculated. The temperature of the testing gas at both inlet and outlet was assumed to be at ambient $\left(\approx 22^{\circ} \mathrm{C}\right)$, because the external gas tube connections were longer than $20 \mathrm{~cm}$, which could cool down the gas from the hot zone in the testing module efficiently. The pressure of the input gas was at 1.05 bar.

\section{Results and discussion}


Figure 4 shows the two individual thick-film Pt thermistors that were fired at back side of the carrier. Their resistance values at room temperature are ca. $32 \Omega$ for the large one and $22 \Omega$ for the small one. The thickness of the fired thick-film Pt was measured to be $2.5 \pm 0.4 \mu \mathrm{m}$, but some sinking into and intermixing with the glass is possible, impacting the electrical properties [14], as the glass transition temperature of both the glass frit in the thick-film Pt thermistors $\left(600^{\circ} \mathrm{C}\right)$ and the glass substrate $\left(717^{\circ} \mathrm{C}\right)$ are lower than the processing temperature $\left(850^{\circ} \mathrm{C}\right)[15$ 16]. The resulting high surface resistance of the thick-film Pt prompted the use of wide meanders $(0.4 \sim 0.6 \mathrm{~mm})$, which benefited on providing an efficient heat transfer to the glass. No crack between the thick-film Pt and the glass substrate was observed after the firing.

Thick-film Ag conductors could not be fired together with the thick-film Pt at high temperature (ab. $650^{\circ} \mathrm{C}$ ), as cracks were seen at the interface between the glass substrate and the thick-film $\mathrm{Ag}$ layer, especially at the overlap area between thick-film Pt and thick-film Ag (Figure 5). The cracks were ascribed to the mismatched thermo-stress between the low-melting glass frit content of the thick-film conductors and the substrate. The coefficient of thermal expansion of glass frit content in thick-film conductors products is usually higher than that of the used glass substrate (3.3 ppm/K) [17]. During firing, both glass frit and glass substrate become less viscous and inter-diffuse, possibly forming initial cracks upon cooling. Therefore, we circumvented this problem by post-firing the thick-film Ag conductors at a lower temperature, which successfully avoided the occurrence of observable cracks when firing below $600^{\circ} \mathrm{C}$. Achieving good bonding to glass was possible to use the low-temperature firing thick-film Ag, ESL 590-G, which was bonded to the glass substrate at $500^{\circ} \mathrm{C}$. In order to improve solder wetting behavior, another $\mathrm{Ag}$ conductor layer (DuPont 6145) with less glass frit content was overprinted and fired togather with the layer of ESL 590-G. This combination of two thick-film Ag conductors was successful in achieving crack-free conduction tracks and solder pads with an average thickness of $40 \pm 5 \mu \mathrm{m}$ and an average resistance of $0.2 \Omega$ at room-temperature. The electromigration of the Ag thickfilm tracks can be a potential failure to the testing platform [18]. However, in this study, using thick film alloy conductor such as Ag-Pd or Ag-Au-Pd instead of the thick-film $\mathrm{Ag}$ materials is limited by their firing temperature $\left(>800^{\circ} \mathrm{C}\right)$, in which the thick-film $\mathrm{Ag}$ conductors cannot cofire with the thick-film Pt thermistor. Therefore, to avoid the issue, the Ag thick-film conductor was only placed at low temperature region where the temperature below $300^{\circ} \mathrm{C}$ was observed. During the test, the average current density of $4.7 \mathrm{~A} / \mathrm{mm}^{2}$ was reached and no electromigration damage of thick-film Ag was observed after operating several hours. Such an issue needs to be further investigated when the platform is running in long term basis.

Figure 4 
Figure 5

Figure 6

Figure 7

Two glass rectangle rings with a width of $0.5 \mathrm{~mm}$ were used to bond both the carrier plates and form separate inlet and outlet fluidic channels (Figure 4, sealing glass = white contrast). A crackfree and hermetic glass seal is desired in order to inhibit any unwanted intermixing of gas. The hermeticity of the glass sealing was determined by the sealing glass paste during the screen printing, the sintering process, the CTE of both used glass frit and substrate as well as its geometry design [19]. The properties of the sealing glass paste and the sintering process were investigated in this study. To achieve a reliable seal and avoid bubble formation, evaporation/burnout of the organic vehicle of the sealing glass paste has to be progressive and complete before densification of the glass by sintering and flow. Using rather high amounts of plasticizer in the paste allows it, in the dried state, to conform to the seal under the influence of the weight, reducing the degree of required flow upon firing. Long sealing time at high temperature (> 10 minutes) and using weights improve glass flow, but can have the adverse consequence of deforming the glass substrates and/or breaking the carrier [20]. Here, the best results were obtained by sealing the carrier at $725^{\circ} \mathrm{C}$ for 20 minutes with a weight of 80 grams; no cracks were observed in the sealing glass layer as verified by the dye penetration test, as shown in Figure 6. The fabricated carrier was cross-sectioned and observed under the microscope. It was observed that the thickness of the inlet fluidic channel is $0.15 \pm 0.01 \mathrm{~mm}$ and its width is $2.71 \pm 0.02 \mathrm{~mm}$ (Figure 7). Using the cross-section area of the fluidic channel, the Reynolds number for the $n$-butane gas is 5 , indicating the gas flow will be laminar. The pressure drop of the inlet $n$-butane gas was estimated at 228 mbar given by the viscosity of $n$-butane (7.4 $\mu \mathrm{Pa} \cdot \mathrm{s}$ at $1.013 \mathrm{bar}$ and $\left.20^{\circ} \mathrm{C}\right)$ and the flow rate $(30 \mathrm{ml} / \mathrm{min})$ according to equation (1) and (2).

\section{Equation 1}

Equation 2

The advantage of the slender bridge design of the carrier is to greatly decouple the thermal conduction along the bridge direction. Figure 8 shows the temperature at the hot and cold ends of the carrier on which the thick-film Pt thermistors were applied a constant voltage of $22 \mathrm{~V}$. The hot end on the carrier easily reached $500^{\circ} \mathrm{C}$ in 3 minutes and finally achieved $700^{\circ} \mathrm{C}$ after 10 minutes, while the cold end stayed below $50^{\circ} \mathrm{C}$ all the time. The thermal loss along the carrier is limited by the high thermal resistance of the Schott AF32 glass substrate (linear thermal conductivity $1.16 \mathrm{~W} / \mathrm{m} / \mathrm{K}$ ), ensuring that conventional low-temperature fluidic and electrical 
connections can be used at the cold end. Although the maximum heating capability of the test module can reach $700^{\circ} \mathrm{C}$, continuous operation above $650^{\circ} \mathrm{C}$ is not recommended, because the temperature would lie close to the softening temperature of both glass frit and AF32 glass substrates, potentially leading to mechanical failure for the device [21,22]. However, such a heating capability of the carrier was totally adequate for the temperature requirement of hightemperature testing and reliability characterization of various devices envisioned for application in the $400-600^{\circ} \mathrm{C}$ range, such as MEMS for $\mu$-SOFCs, catalytic oxidation of hydrocarbons for hydrogen generation, as well as electronics and sensors for harsh environments. For testing the proper working of the gas channels and device bonding, the pressure drop across a catalytic MEMS chip supplied with a gas mixture of air and butane was measured, while the module was heated up from $500^{\circ} \mathrm{C}$ to $550^{\circ} \mathrm{C}$ at constant flow rate. At $500^{\circ} \mathrm{C}$, the pressure drop of the test module was 213 mbar. As the temperature rose, the pressure drop increased to $225 \mathrm{mbar}$ at $525^{\circ} \mathrm{C}$ and $238 \mathrm{mbar}$ at $550^{\circ} \mathrm{C}$. This drop exceeds the effect increasing viscosity. It is therefore believed that the butane was decomposed in the fluidic MEMS device, resulting in expansion of the volume of the carrying gas and thereby of the pressure drop, in agreement with observations made in ref. 7.

Figure 8

Figure 9 describes the power consumption of the thick-film Pt thermistors as temperature increased to $600^{\circ} \mathrm{C}$. The temperature at the hot end increased rapidly to $550^{\circ} \mathrm{C}$, and then slowly reached the target steady-state temperature without overshooting after 12 minutes. The overall power consumption was somewhat over 12 watts in the fast heating-up stage and finally stabilized at about 5 watts, indicating that the system has a relatively good thermal insulation. The power consumed in the system was lost by heat transfer in three manners, namely conduction, convection and radiation. Using a high-reflectance coating inside the thermal insulation such as aluminum foil or silver can reduce the heat transfer from the radiation in order to further decrease the power consumption [23].

Figure 9

\section{Conclusion}

We have developed a micro-scale testing platform for characterizing fluidic MEMS modules at high temperature for applications such as $\mu$-SOFCs or hydrogen generation technology. The carrier in the testing platform offers self-heating temperature regulation capability, convenient low-temperature fluidic and electrical connections, as well as facile hermetic attachment to a micro-fabricated MEMS module. Using thick-film Pt self-heating thermistors, the system can 
easily reach $700^{\circ} \mathrm{C}$ at the hot end, where the device is attached, while the cold end stays below $50^{\circ} \mathrm{C}$. The total power consumption is $5 \mathrm{~W}$ when the system reaches $600^{\circ} \mathrm{C}$ in 12 minutes. The study suggests that the power consumption can be further lowered by means of cutting radiation from the hot end. In future, the $\mu$-SOFC components and the hydrogen reforming through partial oxidation of the hydrocarbon gas will be investigated using the testing platform.

\section{Acknowledgement}

The authors greatly thank all other members of the ONEBAT consortium, especially its coordinator Anja Bieberle, for their collaboration and fruitful discussions. Financial support from the Swiss National Science Foundation (SNSF) within the framework of the SINERGIA project "ONEBAT" (CRSI11_126830) is gratefully acknowledged.

\section{Reference}

[1] A. Bieberle-Hütter, et al., A micro-solid oxide fuel cell system as battery replacement, J. Power Sources 177 (2008) 123-130.

[2] A. Evans, et al., Micro-solid oxide fuel cells: status, challenges, and chances, Monatsh. Chem. 140 (2009) 975-983.

[3] N. M. Sammes, R. J. Boersma, G. A. Tompsett, Micro-SOFC system using butane fuel, Solid State Ionics 135 (2000) 487-491.

[4] Seyed-A. Seyed-Reihani, G. S. Jackson, Catalytic partial oxidation of n-butane over Rh catalysts for solid oxide fuel cell applications, Cata. Today 155 (2010) 75-83.

[5] M.J. Stutz, et al., Fast and energy efficient start-up of micro-solid oxide fuel cell systems by using the reformer or the post-combustor for start-up heating, J. Power Sources, 182 (2008) 558-564.

[6] K.L. Hohn, C.C. Huang, C. Cao, Catalytic ignition of light hydrocarbons, J. Natural Gas Chem. 18 (2009) 115-123.

[7] N. Hotz, N Osterwalder, W. J. Stark, N. R. Bieri, D. Poulikakos, Disk-shaped packed bed micro-reactor for butane-to-syngas processing, Chem. Eng. Sci. 63 (2008) 5193-5201.

[8] L. E. Khoong, Y. M. Tan, Y. C. Lam, Overview on fabrication of three-dimensional structures in multi-layer ceramic substrate, J. Eur. Ceram. Soc. 30 (2010) 1973-1987.

[9] T. Maeder, Y. Fournier, S. Wiedmer, H. Birol, C. Jacq, P. Ryser, 3D structuration of LTCC / thick-film sensors and fluidic devices, in: Proc. $3^{\text {rd }}$ Int. Conf. Ceram. Interconn. Ceram. Microsyst. Technol. (CICMT), Denver, USA, THA13, 2007.

[10] T. Maeder, B. Jiang, Y. Yan, P. Ryser, P. Muralt, Ceramic modules for micro solid-oxide fuel cells, in: Proc. $7^{\text {th }}$ Int. Conf. Ceram. Interconn. Ceram. Microsyst. Technol. (CICMT), San Diego, USA, 2011.

[11] B. Jiang, T. Maeder, P. Muralt, A new platform concept for micro-scale SOFC using low temperature co-fired ceramic technology, in: Proc. $10^{\text {th }}$ Int. Workshop Micro Nanotech. Power Generation and Energ. Conv. App. (PowerMEMS 2010), Leuven, BE, 2010. 
[12] G. Sberveglieri, W. Hellmich, G. Müller, Silicon hotplates for metal oxide gas sensor elements, Microsyst. Technol. 3 (1997) 183-190.

[13] M. Benammar and W.C. Maskell, Temperature control of thick-film printed heaters, J. Phys. E: Sci. Instrum. 22 (1989) 933.

[14] M. Hilali, Effect of glass frit chemistry on the physical and electrical properties of thick-film Ag contacts for silicon solar cells, J. of Elec. Mater. 35 (2006) 2041-2047.

[15] N.M. White and J.D. Turner, Thick-film sensors: past, present and future, Meas. Sci. Technol. 8 (1997) 1.

[16] Data sheet, Schott AF $32^{\mathrm{TM}}$ eco, SCHOTT Germany, Inc.

[17] S.B. Rane et al., Effect of inorganic binders on the properties of silver thick films, J. Mater. Sci.: Mater. Electro. 15 (2004) 103-6.

[18] Y. Mei et al., Migration of sintered nanosilver die-attach material on alumina substrate at high temperatures, in: 2011 12th International Conference on Electronic Packaging Technology and High Density Packaging (ICEPT-HDP), Shanghai, China, 2011

[19] S. Hwang, S. Lee, H. Kim, Sintering behavior of silver conductive thick film with frit in information display, J. Electroceram. 23 (2009) 351-355.

[20] K. Nötzold, C. Dresbach, J. Graf, B. Böttge, Temperature dependent fracture toughness of glass frit bonding layers. Microsyst. Technol. 16 (2010) 1243-1249.

[21] Datasheet of Schott AF 32, Schott AG, 2009

[22] Datasheet of Ferro IP760c, Ferro Corporation, 2011

[23] A. Pike and J. W. Gardner, Thermal modelling and characterisation of micropower chemoresistive silicon sensors, Sensors and Actuators B-Chem. 45 (1997), 19-26. 


\begin{abstract}
Author Biographies
Of Chinese nationality, Bo Jiang was born in Beijing, a 2500 years old city and the capital of the People's Republic of China.

He studies materials science and engineering at Chinese University of Geosciences and obtained his bachelor degree of engineering in 2005. In the same year, he joined research center of Proctor \& Gamble at Beijing in China and involved within developing technologies of Pringles production manufacturing. From 2007, he went to study in Alfred University, New York and received his master of science for his work on high temperature $x$-ray diffraction characterization of chrome poisoning in cathode materials of solid oxide fuel cells. After working shortly at Hybrid Silica Technology, Inc. in Boston MA, where he was in charge of developing silica nano particle production, he moved to Lausanne, Switzerland in 2010. He is carrying out his doctoral research at EPFL regarding to developing thick film technology based microsystem under the supervision by Professor Paul Muralt and Dr. Thomas Maeder.
\end{abstract}




\section{Tables}

Table 1 Fabrication process of GPU with its carrier

\begin{tabular}{cccccc}
\hline Step & Screen printing & $\begin{array}{c}\text { Drying } \\
\text { temperature and } \\
\text { time }\left({ }^{\circ} \mathrm{C} / \mathrm{min}\right)\end{array}$ & $\begin{array}{c}\text { Peak temperature } \\
\left({ }^{\circ} \mathrm{C}\right)\end{array}$ & $\begin{array}{c}\text { Time } \\
\text { (minutes) }\end{array}$ & $\begin{array}{c}\text { Fired } \\
\text { thickness } \\
(\mu \mathrm{m})\end{array}$ \\
\hline I & $\begin{array}{c}\text { Platinum } \\
\text { (CL11-6109) }\end{array}$ & $120 / 10$ & 850 & 10 & $2.5 \pm 0.4$ \\
\hline II & $\begin{array}{c}\text { Sealing glass } \\
\text { (IP760) }\end{array}$ & $150 / 5$ & 725 & 40 & $150.0 \pm 10.0$ \\
\hline III & $\begin{array}{c}\text { Sealing glass } \\
\text { (IP760) }\end{array}$ & $150 / 5$ & 675 & 40 & N.A. \\
\hline IV & Silver (590-G) & $120 / 10$ & & & $40.0 \pm 5.0$ \\
\hline V & Silver (DP 6145) & $120 / 10$ & 575 & 40 &
\end{tabular}




\section{Figures}

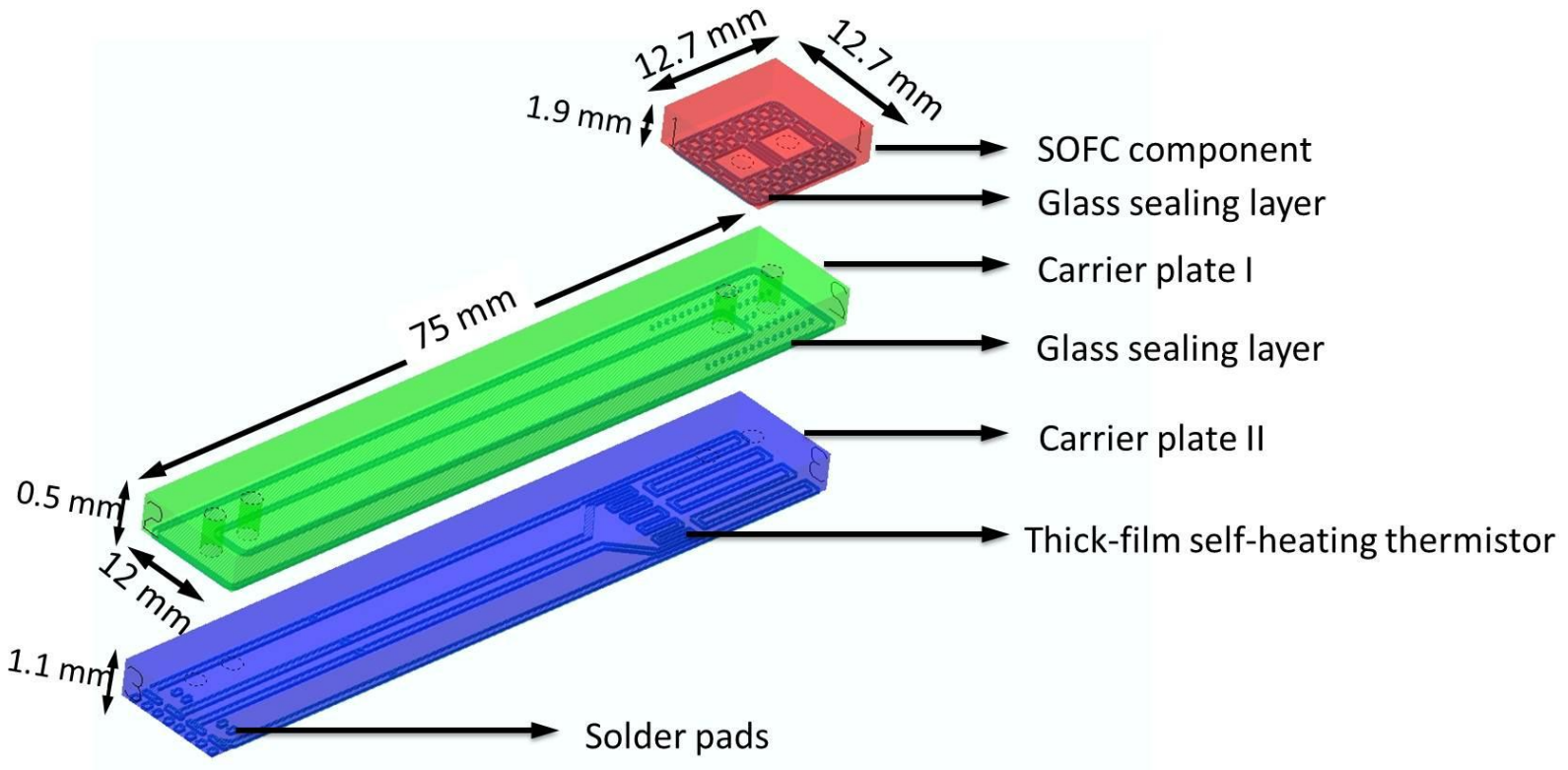

Figure 1 Schematic of high temperature testing carrier concept for testing SOFC components

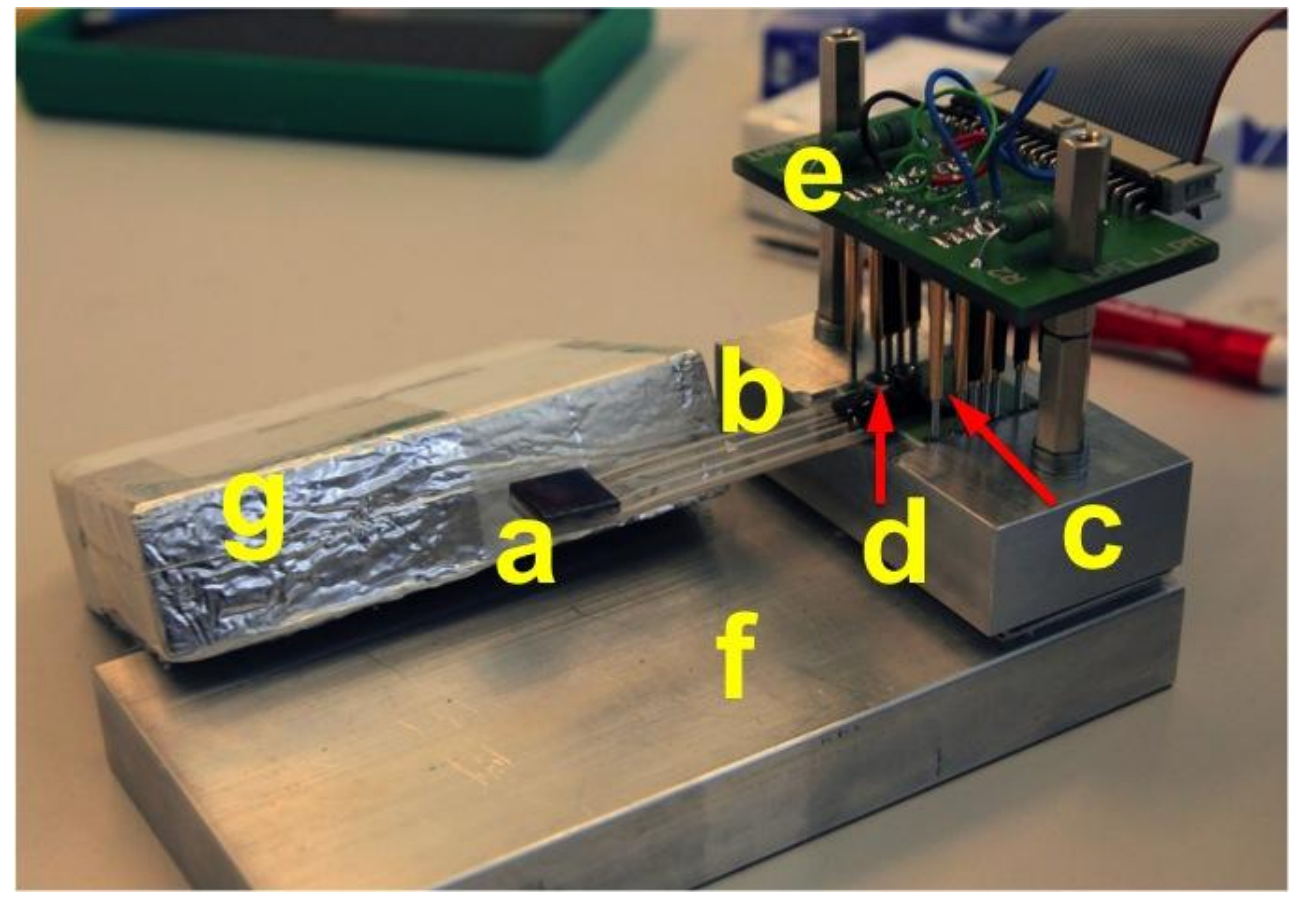

Figure 2 Photograph of assembled testing platform (a: a fluidic MEMS module, b: a carrier, c: a ceramic base, $\mathrm{d}$ : fluidic connectors, e: temperature measurement circuit board for the thick-film Pt thermistor, $\mathrm{f}$ : an aluminum mechanical base, $\mathrm{g}$ : a thermal insulation block). 


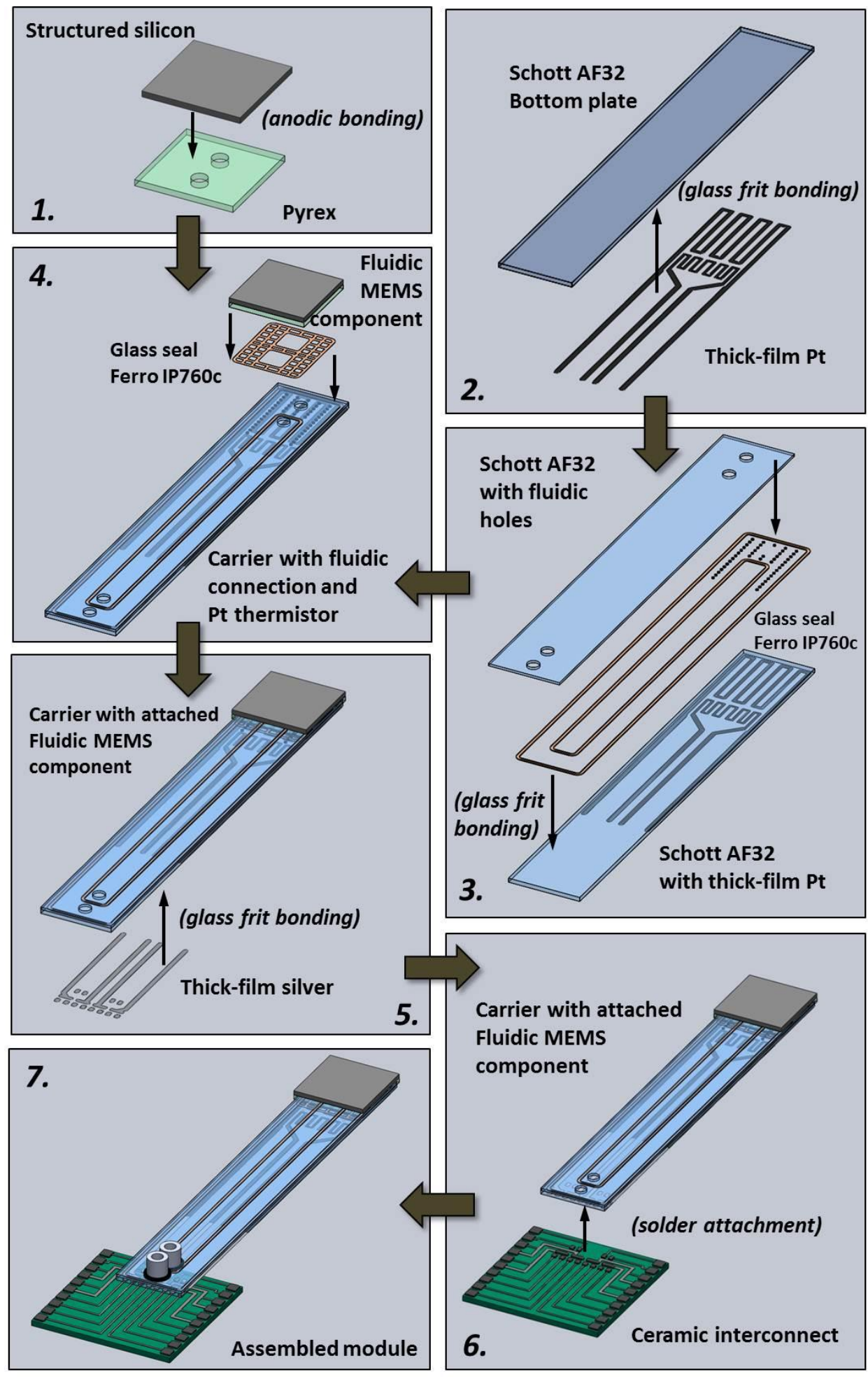

Figure 3 Process flow chart of assembling the testing carrier with a fluidic MEMS module 


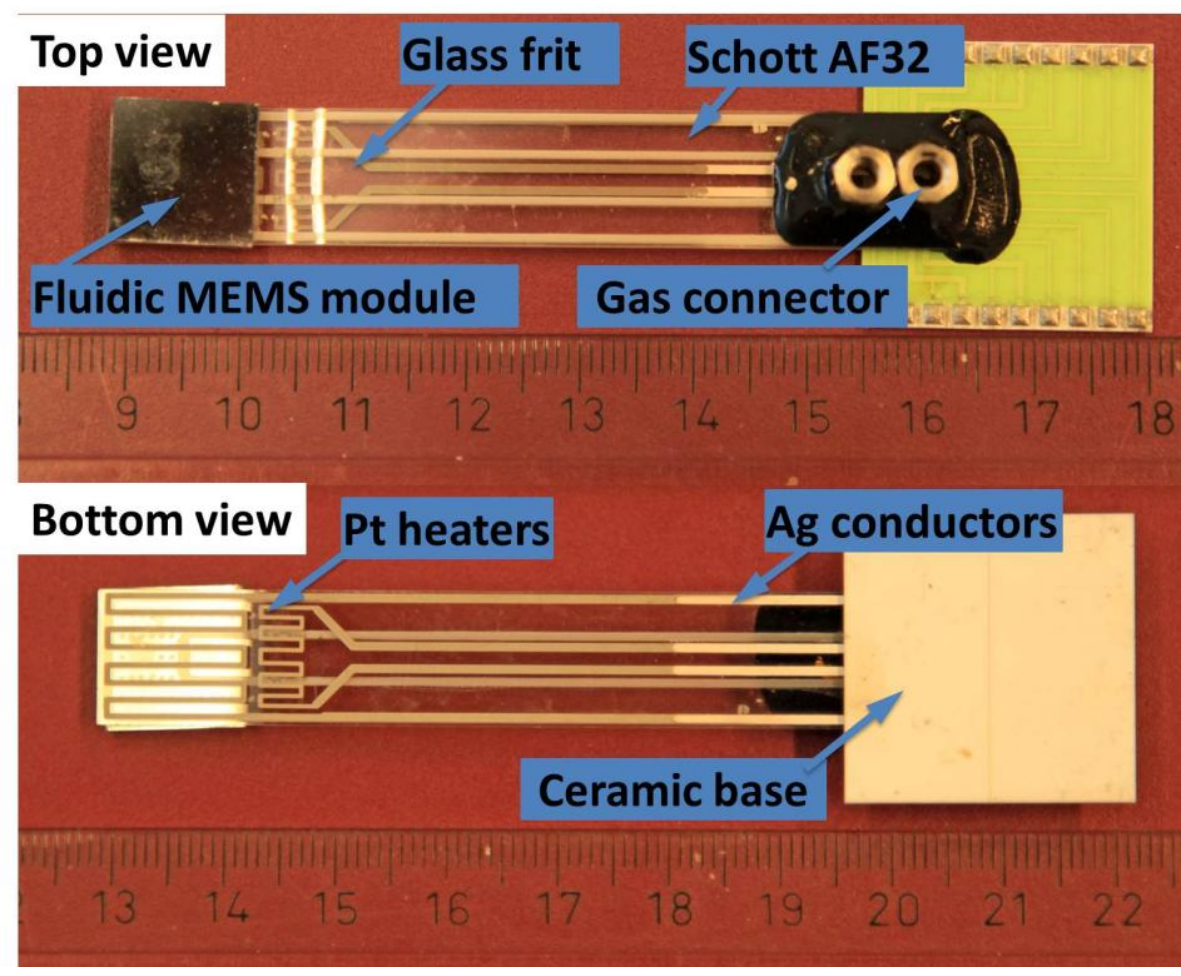

Figure 4 Photograph of top and bottom views of the testing module including a fluidic MEMS module, a carrier with fluidic connectors and a ceramic base.

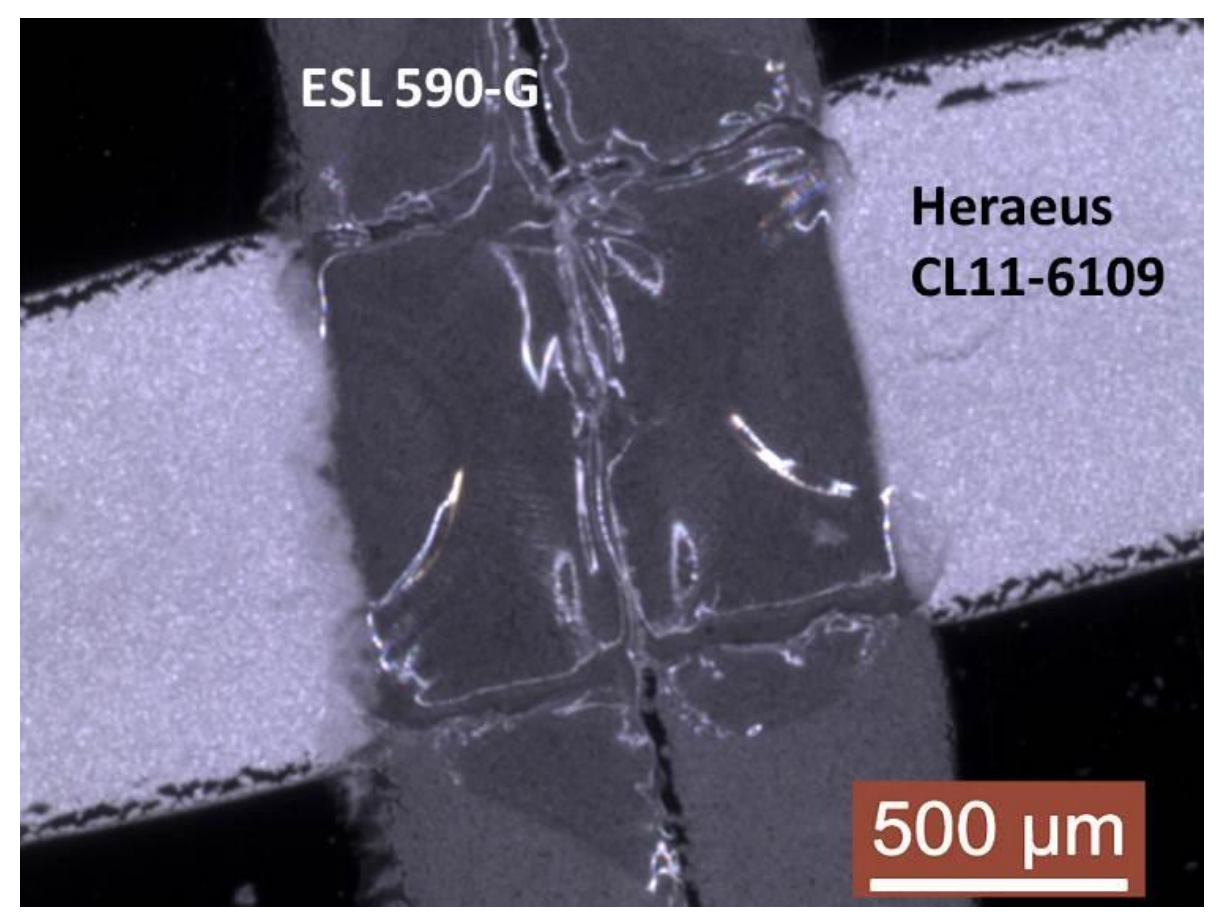

Figure 5 An image of back view of cracks at the interface between thick-film Ag conductor and thick-film Pt thermistor after co-firing at $850^{\circ} \mathrm{C}$ for 10 minutes with a ramp rate of $20 \mathrm{~K} / \mathrm{min}$. 


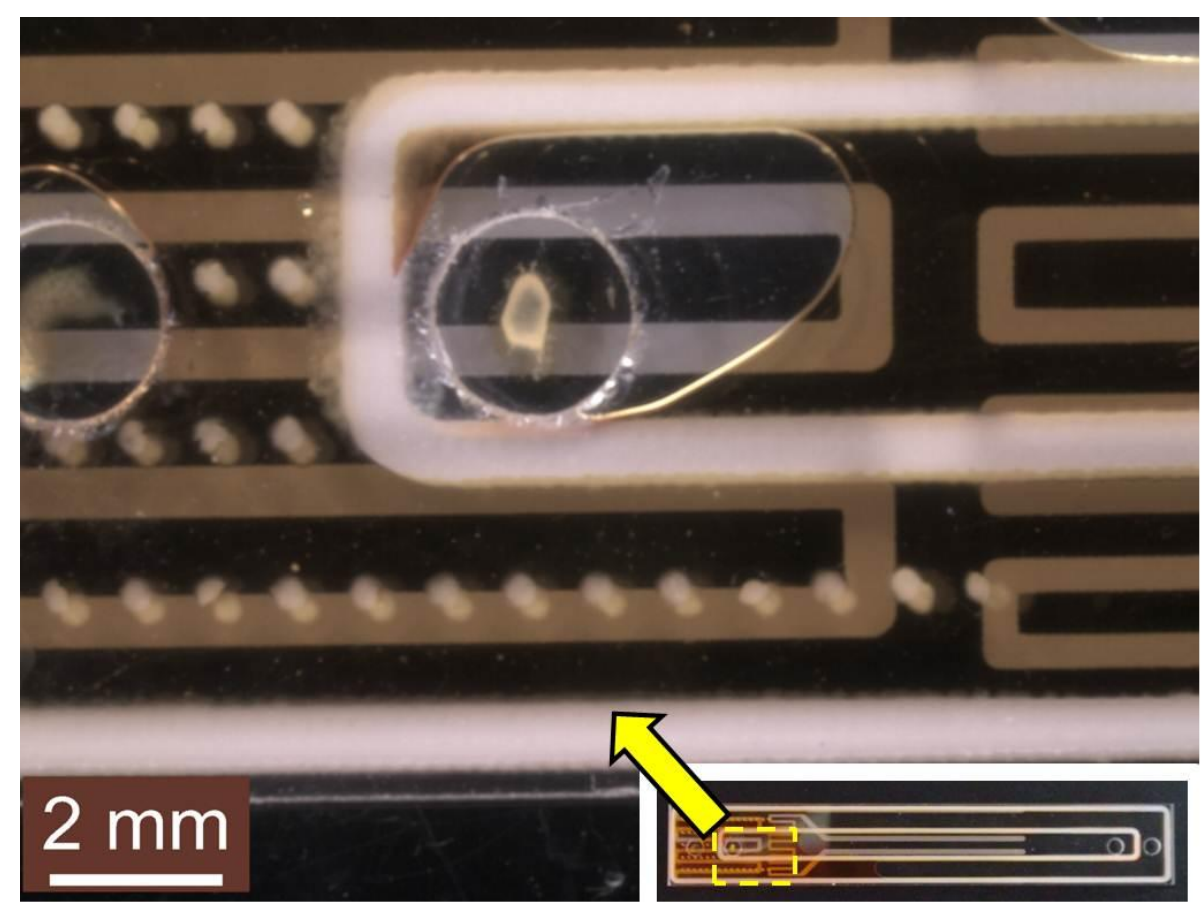

Figure 6 Photograph of dye penetrating testing results on the carrier after the glass sealing process. The main image is a magnification of the entire carrier that was shown right-below, demonstrating the crack-free sealing was obtained.

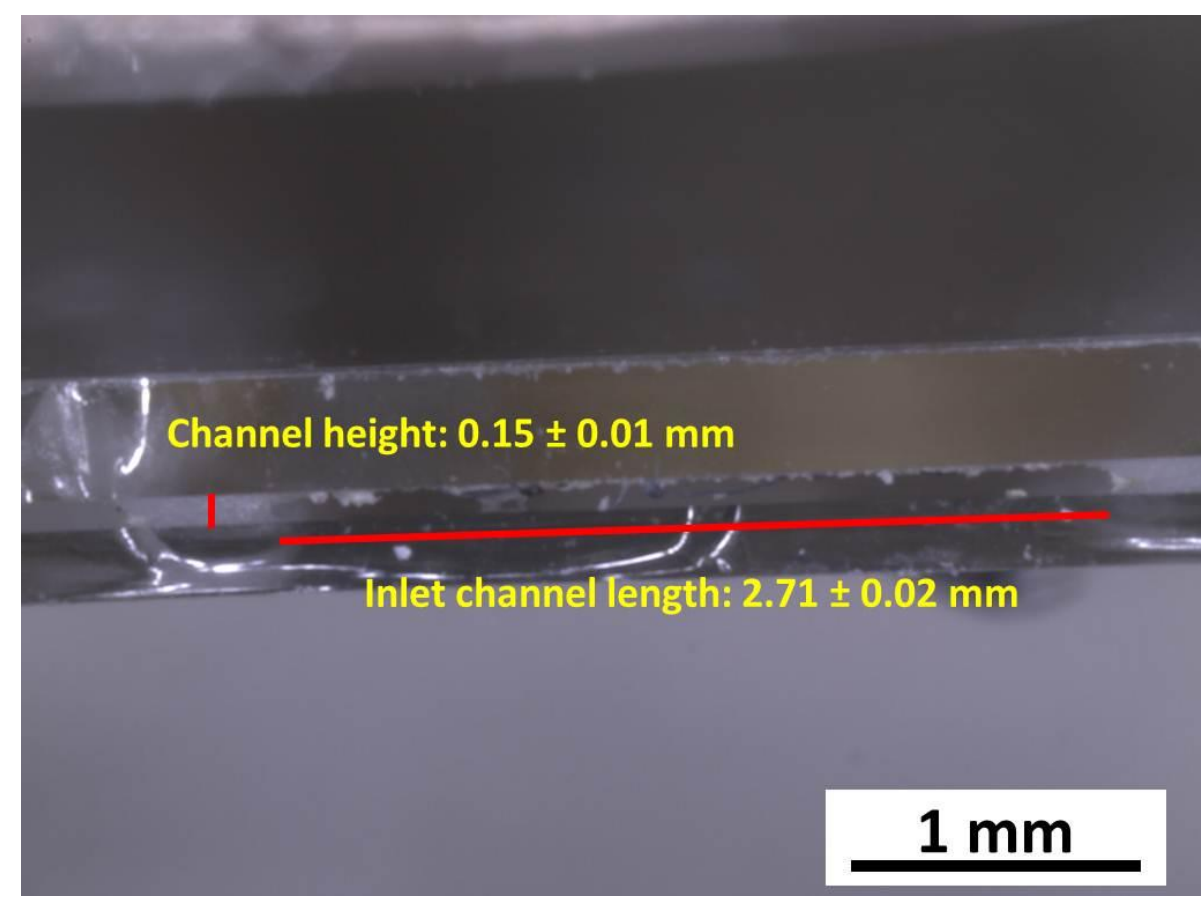

Figure 7 An image of cross-section of fluidic channels in the carrier with measured value of channels width and height. 


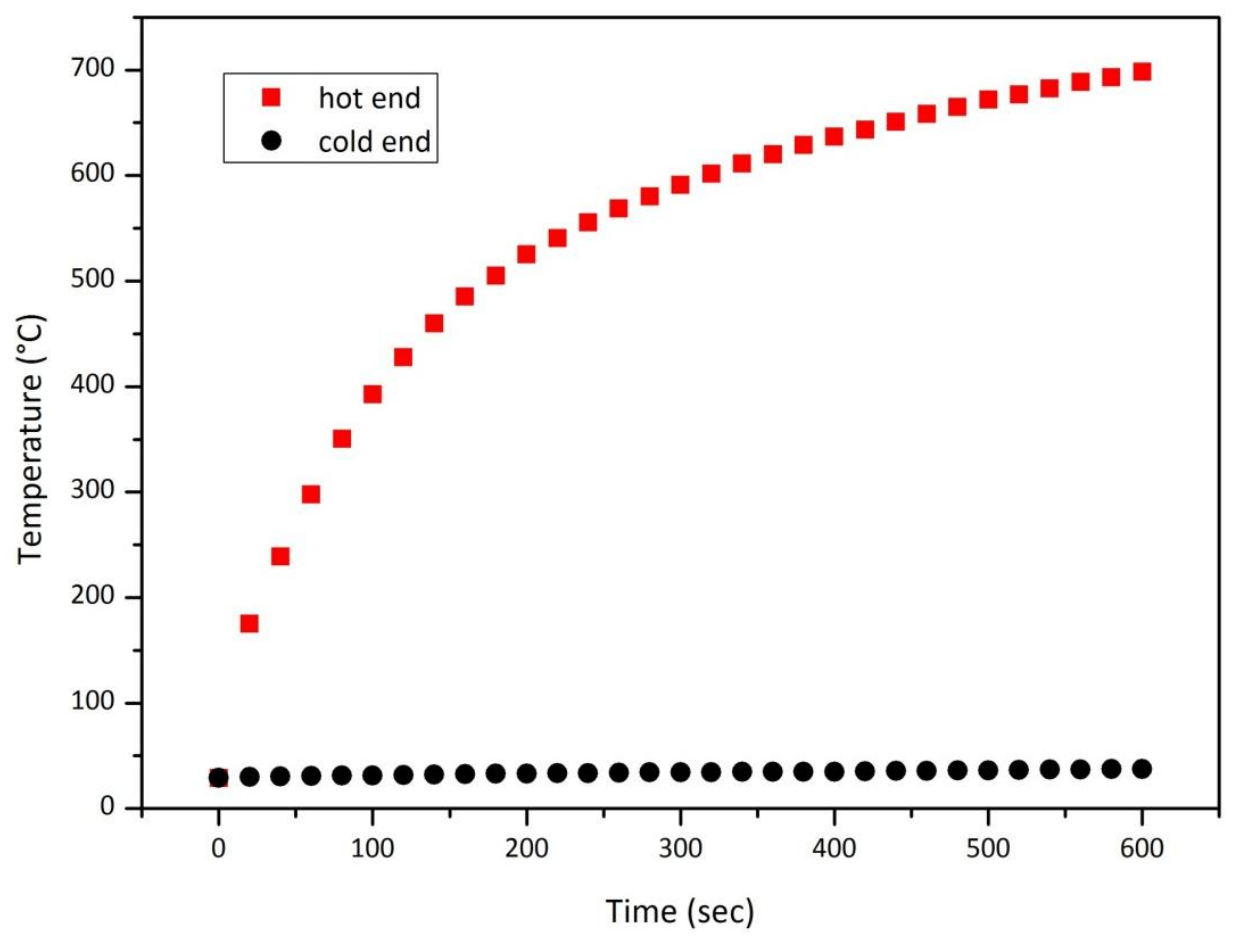

Figure 8 Temperature at the hot (red) and cold (black) ends on the carrier at $22 \mathrm{~V}$ of voltage supplied by the in-house made voltage regulator.

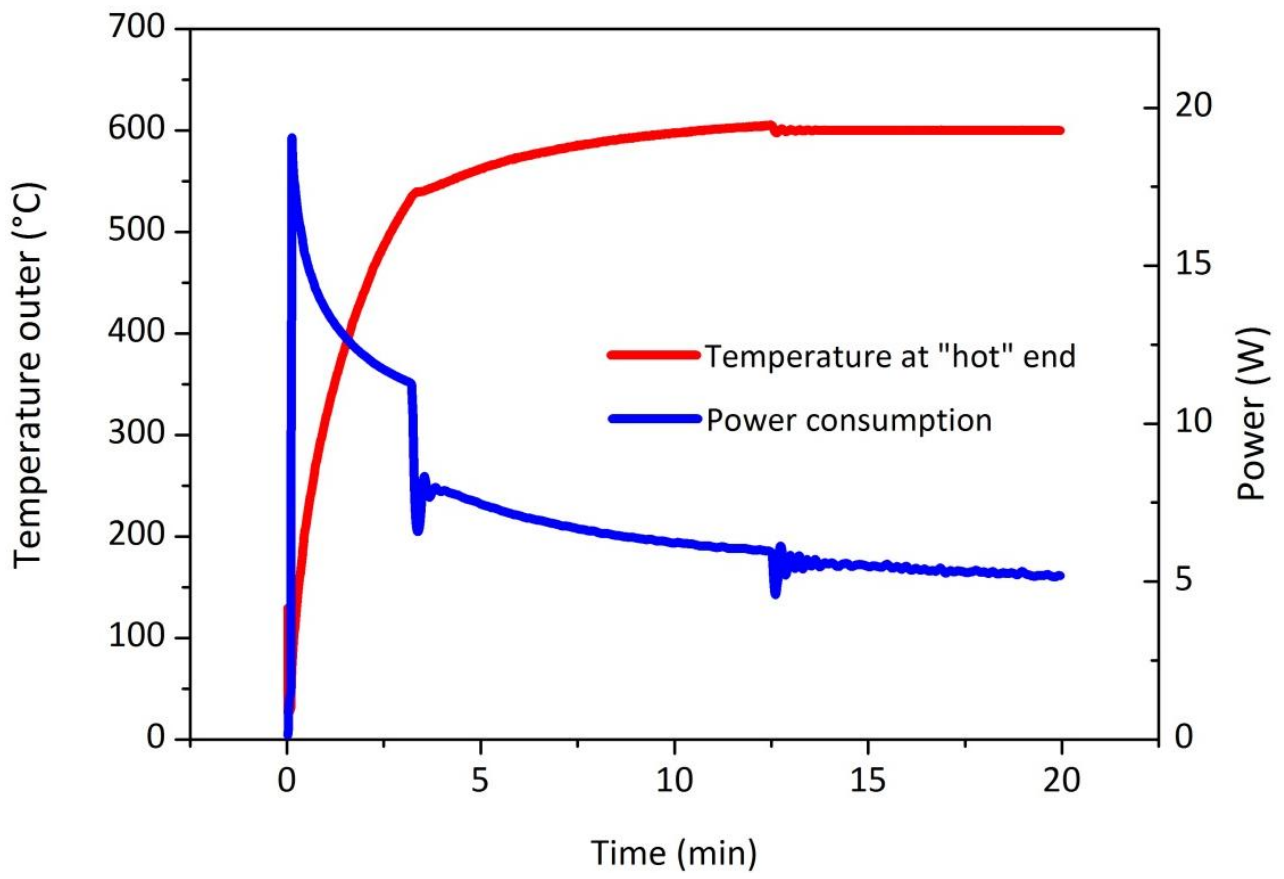

Figure 9 Power consumption and temperature of the thick-film Pt self-heating thermistor at the carrier that is supplied by a voltage regulator whose maximum voltage supply is $22 \mathrm{~V}$. 
Supplementary Material
Click here to download Supplementary Material: Equations_Jiang.docx

Supplementary Material
Click here to download Supplementary Material: Equations_Jiang.docx

pplementary Material: Equations_Jiang.docx

pplementary Material: Equations_Jiang.do

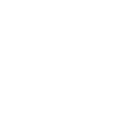

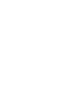

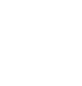
$x^{2}$

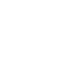

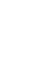

$x^{2}$

(1) $x^{2}$

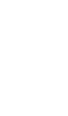

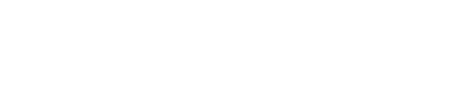

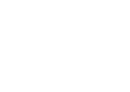
(n)

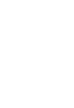

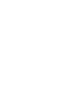

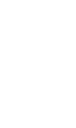

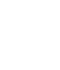

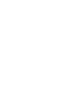

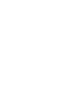

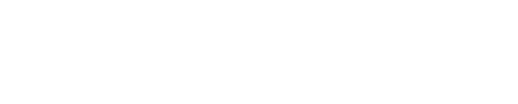

